\title{
The Effect of Unemployment Duration on Future Earnings and Other Outcomes
}

\author{
Daniel Cooper
}

\section{Abstract:}

One of the distinguishing features of the Great Recession and its aftermath has been the spike in the number of individuals experiencing long-duration unemployment spells, defined as lasting more than 26 weeks. This paper analyzes the effect of unemployment duration on an individual's future earnings and other outcomes, such as homeownership and wealth, using data from the Panel Study of Income Dynamics (PSID). The results show a negative relationship between a worker's most recent unemployment spell and his or her current earnings. The earnings of displaced workers do not catch up to those of their nondisplaced counterparts for nearly 20 years. The effect of unemployment on earnings is even more substantial for workers unemployed 26 weeks or more. Unemployment spells also negatively impact future homeownership - this finding suggests that the consequences of the recent spike in unemployment duration could affect more than individuals' expected lifetime earnings. Given the costs of long-term unemployment, policies aimed at reducing the unemployment rate-such as the Federal Reserve's quantitative easing program-could have the added benefit of limiting the negative consequences of long-duration unemployment through fostering faster re-employment.

\section{JEL Classifications: J31, J64, J68}

Daniel Cooper is a senior economist in the research department at the Federal Reserve Bank of Boston. His e-mail address is daniel.cooper@bos.frb.org.

The author extends special thanks to Giovanni Olivei for incredibly helpful discussions regarding this topic and the analysis in the paper. He also thanks Delia Sawhney, Lily Shen, and Kevin Todd for helpful assistance, Danny Blanchflower for initial consultations about this project, and Bill Dickens for a helpful discussion about identification. Thanks as well to seminar participants at the Federal Reserve Board.

This paper presents preliminary analysis and results intended to stimulate discussion and critical comment. The views expressed herein are those of the author and do not indicate concurrence by the Federal Reserve Bank of Boston, or by the principals of the Board of Governors, or the Federal Reserve System.

This paper, which may be revised, is available on the web site of the Federal Reserve Bank of Boston at http://www.bostonfed.org/economic/wp/index.htm.

This version: January 13, 2014 


\section{Introduction}

One feature of the Great Recession and the subsequent sluggish recovery has been persistently high unemployment, and especially a large increase in the percent of unemployed individuals who have been out of work for more than 26 weeks, the period of time that demarks longduration unemployment. Figure 1 compares the distribution of unemployment by duration for individuals in early 2013 compared to individuals at the start of the Great Recession in January 2008. More than twice as many unemployed people had been out of work for more than 26 weeks in February 2013 than in January 2008, and the overall distribution of unemployment has become heavily skewed toward long-duration spells relative to the earlier period. ${ }^{1}$

In September 2012, the U.S. Federal Open Market Committee embarked on a third round of bond buying - known as quantitative easing (QE3) - to help bolster the sluggish recovery and generate sustained improvement in the labor markets. There has been much debate regarding the benefits and costs of QE3. One potential benefit of stimulating the economy and reducing the unemployment rate faster than it otherwise would have fallen in the absence of a bond-buying program is a reduction in long-duration unemployment. This paper uses data from the Panel Study of Income Dynamics (PSID) to examine the lasting costs of longduration unemployment, such as its impact on individuals' future earnings, in order to gauge the potential benefits of reducing overall unemployment more quickly. Such benefits should be weighed against the costs of quantitative easing when determining the program's merits.

The labor market literature contains numerous studies examining the impact of job displacement on individuals' re-employment wages and/or future income. Many of the existing studies use administrative data that includes individuals' earnings and employment histories for this analysis (see Couch and Placzek (2010) for a summary of this literature). More recently Davis and Wachter (2011) found that job displacement causes a sharp drop in workers' earnings, which only gradually over time catch up with the earnings of nondisplaced workers. A key feature of these existing studies is that very few consider how the effect of job displacement on individuals' future earnings varies based on the length of workers' unemployment spells. One notable exception is Addison and Portugal (1989), who use data from the Current Population Survey's (CPS) Displaced Worker Survey in the early 1980s to examine the impact of unemployment duration on individuals' re-employment wages. Recent work that does incorporate unemployment duration into the earnings analysis focuses on European or

\footnotetext{
${ }^{1}$ A similar pattern emerges comparing the distribution of unemployment by duration in February 2013 to the distribution in January 2005. See appendix Figure A.1.
} 
other non-U.S. data (for example, see Gregory and Jukes, 2001; Knight and Li, 2006).

This paper contributes to the literature by examining the relationship between unemployment duration and workers' future earnings using data from the United States that cover earnings and job losses over a roughly 30-year period. The paper compares the earnings trajectories over time of displaced and nondisplaced workers as well as differences in earnings paths for workers that experience short-duration versus long-duration unemployment. In comparison, much of the related literature only focuses on the impact of unemployment duration on the initial re-employment wages of displaced workers. This paper also examines the impact of unemployment and unemployment duration on other long-term outcomes such as homeownership and household wealth. Thus, this paper considers whether long-duration unemployment impacts one's long-term economic prospects beyond any potential earnings effect-something that is not discussed in the aforementioned literature.

The results show a negative relationship between past unemployment spells and individuals' earnings as of 2004. Workers that experience a job displacement of any length have substantially lower wages than nondisplaced workers - an effect that persists for nearly 20 years after the unemployment episode. This earnings gap is even more pronounced for workers whose last unemployment spell was more than 26 weeks compared to those workers who experienced shorter term unemployment spells. In particular, after 10 years the wages of long-term unemployed workers were roughly 32 percent lower than nondisplaced workers, while the wages of short-term unemployed workers were only about 9 percent lower. Conditional on earnings there is also a strong negative relationship between past unemployment episodes and individuals' probability of owning their home in 2005, especially for workers who in the past experienced a long-term unemployment spell. There is less of a relationship between past unemployment and future wealth accumulation.

The remainder of the paper proceeds as follows. Section 2 discusses the existing literature in more detail, and section 3 considers why unemployment duration of any length potentially matters for individuals' future earnings and other economic outcomes. Section 4 discusses the data and estimation sample, section 5 presents the results, and section 6 concludes.

\section{Existing Literature}

Literature reviews in the mid-to-late 1990s (see Fallick, 1996; Kletzer, 1989) showed that job displacement results in persistent earnings losses for workers. Around this same time, Stevens (1997) contributed to the literature by using the PSID to show that much of the persistence 
in earnings losses from job displacement can be explained by workers experiencing additional unemployment spells in the years following their initial job loss. In addition, Nickell, Jones, and Quintini (2002) used British data to examine the duration of earnings losses British men after the end of an unemployment spell, and find fairly persistent effects especially during the 1992-to-1997 period.

In more recent work, Davis and Wachter (2011) examine the impact of job displacement on earnings for individuals in the United States using data from the Social Security Administration. As noted earlier, Davis and Wachter find that job displacement has a strong negative impact on these individuals' income relative to nondisplaced workers. This earnings gap closes over time, but persists for more than 15 years after a job loss. Couch and Placzek (2010), using administrative data on mass layoffs that took place in Connecticut between 1993 and 2004, find that workers have 12 percent lower earnings six years after a mass layoff. An advantage of their study is that they evaluate earnings losses during "normal times" when the unemployment rate was not elevated. Couch and Placzek claim that their analysis helps reconcile the large earnings losses found in administrative datasets during periods of high unemployment with the smaller losses observed in nonadministrative data. Yet neither Stevens (1997) nor these more recent studies consider the impact of unemployment duration on the earnings losses that accrue from job displacement.

A somewhat recent study that does incorporate the role of unemployment duration is Knight and Li (2006). They use a 2000 survey of workers in 13 Chinese cities to examine the relationship between the length of a worker's unemployment spell and his or her re-employment wage. Knight and Li find a negative relationship between unemployment duration and re-employment wages. Previous work by Addison and Portugal (1989) considers a similar question using data from the U.S. Displaced Worker Survey and reaches a very similar and stronger conclusion. Both of these studies, however, are focused on the short-term impact of unemployment duration rather than the long-term effect of unemployment on a worker's future earnings profile.

The previous analysis most closely related this paper is Gregory and Jukes (2001). They use British data to analyze the impact of unemployment on the wages of British men, and their estimates account for differences in unemployment duration. Gregory and Jukes find that it is the duration of unemployment and not the incidence of job displacement that matters most for future earnings in their sample. The period of time over which these authors examine the earnings effect, however, is short - a little over two years. Therefore, while Gregory and Jukes show that unemployment duration matters, they do not consider the same long-term earnings effects that this paper does. 
Overall, the relationship between unemployment spells and future earnings is well studied. The role of unemployment duration has received much less overall attention, especially in terms of long-run earnings effects. In addition, the role of unemployment duration has not been considered lately using data from the United States, which recently experienced the most severe economic downturn since the Great Depression. The effect of unemployment duration on future income is particularly relevant for determining economic and monetary policy given the slow U.S. recovery that has been characterized by persistently high unemployment and extended unemployment spells for displaced workers. In addition, the existing studies do not consider the impact of unemployment itself or unemployment duration on other outcomes such as the future homeownership status of displaced workers.

\section{Theoretical Framework}

\subsection{Background}

Gregory and Jukes (2001); Knight and Li (2006); Addison and Portugal (1989) provide useful theoretical backgrounds and frameworks regarding why job displacement and unemployment duration matter for individuals' re-employment and/or future wages. This section summarizes the main ideas from those frameworks, drawing heavily on the discussion in Gregory and Jukes (2001). The first key idea is that job displacement results in lost human capital. On the job, workers often acquire firm-specific skills that are not necessarily transferable to other companies. As a result, a new position where these skills are not valued will likely pay a lower wage, at least initially, until the worker acquires the skills that are valued by the new employer. In addition, the longer a worker is unemployed, the more his or her skillsfirm-specific or not-depreciate, making the worker less valuable to a new employer. This situation again translates into receiving a lower initial wage at a new job. As a worker's human capital is rebuilt over time in a new job, his or her wage should rise and a crucial question is whether the wage ever catches up to where it would have been in the absence of a job loss.

The implications of the job search literature contrast with those studies that attribute lower wages to reduced human capital and firm-specific skills. Specifically, in standard search models long-duration unemployment implies that an unemployed worker seeking a new job has not found an employment opportunity where the wage on offer exceeds his or her reservation wage. In other words, standard search models posit that workers use the job search process as a way to improve their position in the labor force. Since wages are tied to worker 
productivity, a longer search process is expected to result in a better employer-employee match and a higher wage for the employee. In this context, unemployment duration is associated with higher future earnings. Of course, these models assume that bad job matches are destroyed and good matches are created. If a good job match is destroyed and the worker cannot find a comparable or better opportunity, then there would be an earnings loss associated with longer unemployment duration.

A final theoretical interpretation of the link between unemployment duration and earnings is based on signaling. Employers do not necessarily have perfect information about prospective new hires and look at their job histories as a proxy indicator of their abilities. Job histories that include frequent and/or long-term unemployment spells - especially spells due to reasons other than mass layoffs and/or plant closings - may be viewed as a sign that

a job candidate is less productive than others or a so-called bad apple. Such a situation will likely cause the firm to offer a low wage to the new hire, at least until the new employer can better observe the individual's on-the-job performance for themselves.

Given the multiple possible interpretations of the relationship between unemployment spells and workers' future earnings, establishing the actual relationship becomes an empirical exercise. Like Gregory and Jukes (2001), this paper considers how the incidence and duration of past unemployment spells, as well as the number of years since a worker's most recent job loss, impact the relationship between unemployment spells and future earnings.

\subsection{Estimation Approach}

\subsubsection{Earnings}

The underlying model for this paper's main analysis is a modified version of the standard Mincerian earnings function (Mincer, 1974). In particular, earnings $W$ for an individual $i$ at time $t$ are assumed to be a function of the individual's education $S$, experience $E$, ability $A$, and job type $T$ :

$$
W_{i t}=f\left(A_{i t}, S_{i t}, E_{i t}, T_{i t}\right)
$$

Worker ability is an all-encompassing term for measures of worker quality, while job type captures job quality - two relevant factors omitted from the standard Mincer equation as discussed by Abraham and Farber (1987) and others. Equation 1 omits a measure of job match quality between the employer and employee and/or the employee and the actual position within the firm, since it cannot easily be observed. 
Implementing equation 1 results in the following estimation model:

$$
\begin{aligned}
w_{i t} & =\beta_{0}+\beta_{1} w_{i t-j}+\beta_{2} \text { tenure } e_{i t}+\gamma \mathbf{e}_{\mathbf{i t}}+\text { occc }_{\mathbf{i t}} \\
& +\eta \mathbf{i n d}_{i t}+\nu \mathbf{X}_{i t}+\epsilon_{i t}
\end{aligned}
$$

where $w_{i t}$ is the individual's log wages at time $t, w_{i t-j}$ is the individual's log wages $j$ periods prior to the current period, tenure ${ }_{i t}$ captures the number of years an individual has been at his or her current job, $\mathbf{e}_{i t}$ is a vector of dummy variables for an individual's education level, $\mathbf{o c c} c_{i t}$ is a vector of dummy variables representing different occupations, $\mathbf{i n d}_{\mathbf{i t}}$ is a vector of dummy variables for different industries, $\mathbf{X}_{i t}$ is a vector of additional controls that matter for workers' earnings such as age and gender, and $\epsilon_{i} t$ is an individual-specific error term that captures unobserved individual characteristics that impact workers' wages.

An individual's lagged wage is included to capture his or her ability as well as other workerspecific wage determinants that would otherwise end up in the error term of equation 2. Previous wages should reflect an individual worker's characteristics such as whether the worker is reliable, hardworking, and/or, relatively speaking, a so-called good apple or bad apple. In sum, past wages reflect the worker's capacity to earn a high wage versus a low wage. A worker's occupation and industry provide a measure of job quality, while tenure captures a worker's job experience. The education dummy variables account for whether a worker has dropped out prior to completing high school, graduated from high school, attended some college, graduated from college, or completed an advanced degree. Finally, the vector of additional controls include a cubic term for the worker's age, race, and sex, as well as state fixed effects. Age is an additional indicator of worker experience and earnings capacity, sex and race capture potential wage differentials across worker types and/or may proxy in part for worker quality, and the state level controls capture any regional differences in wages.

To analyze the questions of interest for this paper, variables related to a worker's past unemployment spells (if any) and unemployment duration (if any) are added to equation 2 ,

$$
\begin{aligned}
w_{i t} & =\alpha_{0}+\alpha_{1} w_{i t-j}+\alpha_{2} u e_{i}+\alpha_{3} u e_{i} *{y r s s_{i}}+\alpha_{4} d u r_{i}+\alpha_{5} d u r_{i}^{2} \\
& +\gamma \mathbf{Z}_{i t}+u_{i t}
\end{aligned}
$$

where $u e_{i}$ is an indicator variable for whether or not the individual has suffered an unemployment spell in the past, $y r s s_{i}$ is the number of years since that spell, $d u r_{i}$ is the duration 
(in weeks) of the spell, and $\mathbf{Z}_{\mathbf{i t}}$ includes the vector of controls $\left(\mathbf{X}_{\mathbf{i t}}\right)$ from equation 2 along with the other variables in that equation that predict an individual's future earnings. When an individual has more than one past employment spell, the most recent episode is used for the analysis. ${ }^{2}$ In addition, $\mathbf{Z}_{\text {it }}$ includes an individual's total number of past unemployment spells. Equation 3 is similar to the empirical approach used in Gregory and Jukes (2001).

There has been much discussion regarding individuals unemployed for 26 weeks or less (short-term unemployed) versus individuals unemployed for more than 26 weeks (long-term unemployed). The 26-week cutoff is based on the fact that standard unemployment insurance (UI) in the United States only lasts 26 weeks. Congress extends UI benefits beyond 26 weeks during periods of particularly high unemployment, like during the Great Recession, but these extended benefits are temporary and not available during periods when the U.S. unemployment rate is not substantially elevated. The 26-week split for determining short-term versus long-term unemployment is economically meaningful because while some individuals may wait to find a job until their UI benefits are nearly exhausted, long-term unemployed individuals have likely not found a good enough match for a new job or are lower quality workers who firms are less inclined to hire. There also may be a stigma associated with long-term unemployment that impacts individuals' ability to find a new job and/or the wage they earn once re-employed.

This widely used definition based on the UI benefit cut-off to distinguish between shortterm and long-term unemployment provides a specific functional form-a nonlinearity at 26 weeks of unemployment - that is potentially better for identifying the unemployment duration effects than the more general quadratic term in equation 3. Incorporating the short-term and long-term unemployment duration split yields the following alternative specification:

$$
\begin{aligned}
w_{i t} & =\eta_{0}+\eta_{1} w_{i t-j}+\eta_{2} u e_{i}^{l 6}+\eta_{3} u e_{i}^{l 6} * y r s s_{i}+\eta_{4} u e_{i}^{6 p}+\eta_{5} u e_{i}^{6 p} * y r s s_{i} \\
& +\omega \mathbf{Z}_{i t}+u_{i t}
\end{aligned}
$$

where $u e_{i}^{l 6}$ is an indicator variable that equals 1 if an individual's past unemployment spell lasted 26 weeks or less, and $u e_{i}^{6 p}$ is an indicator that equals one if the past spell lasted more than 26 weeks. The rest of the variables and the empirical setup are the same as in equation 3. In principle, the quadratic duration term could be included in equation 4 as well to test whether indicators for short-term and long-term unemployment and the actual number of weeks someone was unemployed both matter for future earnings.

\footnotetext{
${ }^{2}$ Alternative approaches such as using an individual's longest unemployment spell yield similar results.
} 


\subsubsection{Other Outcomes}

This paper also examines the impact of past unemployment spells and unemployment duration on future homeownership and household wealth holdings. These relationships are calculated by substituting out the dependent variable in equations 3 and 4 . For example, to estimate the impact of past unemployment on future homeownership, equation 4 is modified as follows:

$$
\begin{aligned}
h o_{i t} & =\eta_{0}+\eta_{1} h o_{i t-j}+\eta_{2} u e_{i}^{l 6}+\eta_{3} u e_{i}^{l 6} *{y r s s_{i}}+\eta_{4} u e_{i}^{6 p}+\eta_{5} u e_{i}^{6 p} * y r s s_{i} \\
& +\omega \mathbf{Z}_{i t}+u_{i t}
\end{aligned}
$$

where $h o_{i t}$ is an indicator that takes the value of 1 if the individual is a homeowner at time $t$ and is zero otherwise, and $h o_{i t-j}$ is a homeownership indicator $j$ periods earlier. For financial wealth, the dependent variable is financial wealth (excluding housing) relative to income in period $t$. The estimates similarly control for financial wealth relative to income in period $t-j \cdot \cdot^{3}$

\subsection{Timing and Discussion}

The data used to estimate equations 3 and 4 are discussed in more detail in section 4 . In terms of timing, however, $w_{i t}$ is defined an individual's real labor income as of 2004, while $w_{i t-j}$ measures an individual's average real labor income between 1994 and 1996. An average is taken to reduce measurement error, although alternative specifications of past earningsincluding earnings at a given (younger) age of the worker - yield very similar results. Earnings from 2004 (the 2005 survey year) are used to maximize the potential length of time since an individual's unemployment spells, and also avoid any confounding effects due to the housing collapse and start of the Great Recession.

Given this timing approach, equation 4, for example, becomes:

$$
\begin{aligned}
w_{i, 2004} & =\eta_{0}+\eta_{1} \bar{w}_{i, 1994-96}+\eta_{2} u e_{i}^{l 6}+\eta_{3} u e_{i}^{l 6} * y r s s_{i}+\eta_{4} u e_{i}^{6 p}+\eta_{5} u e_{i}^{6 p} * y r s s_{i} \\
& +\omega \mathbf{Z}_{i t}+u_{i t} .
\end{aligned}
$$

\footnotetext{
${ }^{3}$ Financial wealth and homeownership are measured at the household level due to data availability, as discussed in section 4 .
} 
An alternative timing and estimation approach would be to measure individuals' earnings at set intervals since their most recent unemployment spell (one-year, two-years, and so on). Gregory and Jukes (2001) and Nickell, Jones, and Quintini (2002) employ this approach but both studies have more frequent (quarterly) data on household unemployment spells and earnings and are more interested in the short-run dynamics of unemployment and earnings. Measuring earnings at a specific point in time seemed appropriate given the goals of this paper. It is also easier to draw parallels between this type of wage equation and the equations used to estimate the impact of unemployment on other economic outcomes.

An important issue when estimating equation 6 and the equivalent version of equation 4 is that individuals with no earned income in 2004 are excluded from the analysis since their log wages are undefined. Excluding these zero earners when estimating wage equations (even in levels) is standard practice in the labor literature; however, this omission ignores a potentially important selection issue. In particular, an individual's labor force participation decision impacts whether or not he or she has positive earnings, and past spells of unemployment may effect an individual's decision whether to remain in the labor force. Someone that has experienced multiple unemployment spells and/or a difficult time finding a job after his or her most recent job loss may decide to drop out of the labor force rather than continue searching for a new job. In such a situation there is a relationship between an individual having zero earnings and their employment duration that is ignored by excluding zero earners from the sample. Ignoring these workers who have dropped out of the labor force due to past unemployment spells may result in an inaccurate estimate of the relationship between unemployment duration and an individual's future earnings. The results in section 5 include estimates that explicitly control for this potential selection bias. Estimates of the impact of unemployment on future homeownership or wealth holdings are not restricted to workers with non-zero earnings, and thus do not suffer from this selection bias. These estimates also provide an additional check of the sample selection issue.

Another potential estimation issue arises from the suggestion in the job search literature that unemployment duration and subsequent earnings are jointly determined. As noted earlier, a worker's reservation wage impacts the length of time he or she searches for a job. The longer a worker searches, the more likely he or she is to receive an offer that exceeds his or her reservation wage. At the same time, however, the wage offers a worker receives impact the duration of his or her search. This simultaneity problem is much more of an issue in studies, such as Addison and Portugal (1989), that examine the impact of unemployment duration on individuals' re-employment wages rather than the longer-term impact of unemployment duration on individual's earnings. Over time a worker's wages should be tied more to his or 
her productivity and less to the length of the job search.

Still, one might be concerned that unemployment duration may provide a signal about match quality. To the extent such signalling occurs, longer unemployment spells should have less of an effect on future earnings, thus biasing this paper's estimates against finding an impact of unemployment duration on an individual's future income. That is, under this signalling scenario this paper's estimates would provide a lower bound of the true effect.

Unemployment duration could also be endogenous to the extent it is correlated with unobserved worker quality or some other component of the error term in equations 3 and 4. With time, however, an employer should be able to better observe worker quality and adjust the worker's wage accordingly. Longer-duration unemployment could also proxy for skill (human capital) loss to the extent that a worker must settle for an inferior (less skilled) position in order to be re-employed. For example, a long-term unemployed manufacturing worker might be forced to accept a service industry job in order to earn a living. Conditioning the estimates of equations 3 and 4 on observables such as whether or not a worker has changed industries since his or her last unemployment spell helps control for such endogeneity.

\section{Data and Estimation Sample}

\subsection{PSID Overview}

The data used in this paper come from the PSID, which is a household-level survey that began in 1968 and follows households and their offspring over time. Sixty percent of the initial 4,800 surveyed households belong to a cross-national sample from the 48 contiguous states, while the other portion is a national sample of low-income families from the Survey of Economic Opportunity. The survey was conducted annually through 1997 and biennially thereafter. The most recent wave of the PSID (2011) includes close to 9,000 households.

The PSID is particularly useful for this paper's analysis because it tracks the labor market status and earnings of the head of the household and his or her spouse (if any) along with other labor market characteristics such as the industry and occupation in which they work. This paper includes only heads of the household in the analysis because their earnings and employment records tend to be more complete and stable over time. Spouses enter and exit the labor force more frequently for reasons other than job displacement - such as taking time off to care for children - and thus their earnings are much more variable and intermittent over time.

Earnings and labor market status (unemployment and so on) are reported for the year 
prior to the survey year (for example, 2004 for survey year 2005). Depending on the PSID wave, individuals report either the number of weeks or the number of hours they were unemployed. Heads of household are divided based on whether or not they were unemployed in a given year for more than the equivalent of 26 weeks. ${ }^{4}$ A worker's tenure at his or her current job is calculated based on how long he or she reports being with the current employer. ${ }^{5}$

The PSID also contains information on households' housing tenure (owner versus renter) in every wave as well as detailed wealth data in 1984, 1989, 1994, and 1999 onward. The homeownership variable takes a value of 1 if the household owns its living quarters and is 0 otherwise. These data are assigned to the household head for the purposes of analyzing the impact of unemployment spells on other economic outcomes. Where applicable, nominal dollar values are converted to real dollars using the PCE deflator (2000 base year).

The small sample size of the PSID compared to the large administrative datasets used by Davis and Wachter (2011) and others to examine job displacement effects, may limit the precision of this paper's estimates. The PSID income data are also self-reported, and are thus subject to greater measurement error than the administrative data. But using the PSID has the advantage of including data on other economic outcomes beside earnings, and it permits controlling for the duration of a worker's unemployment spell, not just whether a job displacement event has occurred. Estimates using the PSID can also control for past worker attributes and behavior that are not available from their administrative employment records.

\subsection{Estimation Data and Sample}

The estimation sample is restricted to heads of household, and earnings (labor income) are measured as of 2004 (the 2005 survey year data) so heads of household must be in the 2005 wave and have positive labor earnings to be included in the baseline analysis. The positive earnings restriction is relaxed when an individual's selection into the labor force is taken into account using a two-step Heckman estimator. In addition, labor income is comprehensive and potentially includes earnings from multiple jobs, so the estimates control for the household head's reported number of jobs worked in 2004.

Unemployment spells are recorded between 1977 and 2000 (the 2001 survey year): the

\footnotetext{
${ }^{4}$ Individuals only report their total amount of unemployment so it could encompass one episode or multiple episodes.

${ }^{5}$ The job tenure data are used to create an implied job start date in each PSID wave. When this approach results in discrepancies across years for the same job, the earliest or most frequently reported start date is used. For example, suppose an individual's implied (reported) start date for his or her job in the 1990, 1991, 1992, and 1993 PSID waves are 1978, 1980, 1978, and 1978, respectively, then a start date of 1978 is used to calculate the worker's tenure at that job in all years (1990 to 1993).
} 
most recent spell is used for individual's with more than one period of unemployment. ${ }^{6}$ Since this paper is interested in the long-term effect of unemployment on earnings, individuals with unemployment episodes after 2001 are excluded from the analysis. This restriction ensures that at least three years have elapsed since an individual's last unemployment episode, which is important given this paper's emphasis on examining the long-term impact of unemployment episodes on workers' earnings. Table 1 shows that there is a fair amount of variation in the number of years since an individual's last unemployment spell, although this distribution is skewed toward more years having elapsed given the sample restrictions plus the strong economy and low aggregate unemployment present in the late 1990s.

The estimates are further restricted to individuals who are 25 to 65 years old. Workers must also reside in the United States, rather than currently live in a foreign country. In order to maximize the size of the sample, individuals with missing or nonclassified industry or occupation data are assigned the reported industry or occupation of their first job (when available). ${ }^{7}$ The final sample includes 2,454 individuals. Table A.1 in the appendix shows the contributions of each of the sample restrictions to the final sample size. Summary statistics for the estimation sample are shown in Table A.2.

\section{Results}

\subsection{Earnings}

\section{Baseline Estimates}

Table 2 presents the baseline results, with column 1 showing estimates of equation 3. As in the existing literature, unemployment spells have a large negative impact on earnings, which are roughly 31 percent lower (on impact) for displaced workers compared to those individuals that do not experience an unemployment spell. This negative earnings effect dissipates over time, with individuals' incomes recovering almost 2 percent a year after the initial drop. Still, 10 years after an unemployment spell, a worker's labor income is almost 14 percent lower than it would have been in the absence of experiencing a job displacement. Displaced workers' income fully recovers only after about 19 years - somewhat faster than the recovery time found in Davis and Wachter (2011).

In addition, the coefficients on the unemployment duration terms suggest that for a given number of years since an unemployment spell, someone who was unemployed for 40 weeks

\footnotetext{
${ }^{6}$ Individual and head of the household are used interchangably and refer to the same group of respondents.

${ }^{7}$ Industry data are replaced for 50 household heads, and occupation data are replaced for 86 heads.
} 
had nearly 1.5 percent lower earnings than someone unemployed for only 10 weeks. This difference is precisely estimated (p-value 0.09) and suggests that unemployment duration effects the relationship between job displacement and an individual's future earnings.

The estimates in column 3 distinguish between prior short-duration and long-duration unemployment - individuals whose unemployment spell was 26 weeks or less and those who had an episode lasting 27 weeks or longer (equation 4). The results suggest a relatively large differential effect on future earnings for short-duration versus long-duration unemployment. Past unemployment lowers wages on impact about 24 percent for short-term unemployed workers, compared with a 67 percent drop for long-duration unemployed workers. ${ }^{8}$ The earnings of long-term unemployed workers recover more quickly-more than double the rate of recovery for short-term workers' wages - but even 10 years after a worker endured a longterm unemployment spell, he or she earns 32 percent less than nondisplaced workers, while the wages of workers who had a short-term unemployment spell are only about 9 percent lower. The earnings gap also closes about three or four years sooner for short-term unemployed workers than for long-term unemployed workers.

Including both the discontinuous treatment of unemployment duration with the nonlinear but continuous (quadratic) treatment does not noticeably alter these overall results and conclusions (column 5). The coefficients on the quadratic duration terms suggest that within a given duration category (short-term versus long-term), the wage loss increases with additional weeks of unemployment. This difference, however, is not large and the main duration effect comes from separating individuals based on whether they were unemployed for 27 weeks or more.

Other estimated coefficients of the wage equation have the expected signs and are similar across specifications. In particular, current earnings are positively related to past earnings, and income rises with one's amount of education. Male earnings are also higher on average than female earnings - consistent with the literature on the gender wage gap. Longer tenure at one's current employer also results in higher wages, likely because firms are better able to observe a worker's quality and productivity and pay him or her accordingly.

In contrast, wages are lower the more unemployment spells a worker has experienced, and are nearly 10 percent lower, on average, for workers that are employed in a different industry than the one they were in prior to their (last) unemployment episode. Multiple unemployment spells likely hinder career growth because a worker lacks enough lengthy employment stints at any one firm to become increasingly productive and fully signal his or her abilities. As a

\footnotetext{
${ }^{8}$ This difference is borderline significant (p-value 0.13 )
} 
result, he or she likely never gets on a stable wage growth path over time. Lower wages due to a worker changing industries is likely related to firm-specific skill loss and/or a worker's inability to find a good re-employment match, perhaps due to the increased destruction of good jobs. That is, the worker may have to settle for a less-skilled or lower paying position to regain employment - such as a manufacturing worker being forced to switch to a service sector job after the factory job was outsourced to another country.

\section{Controlling for Selection}

Columns 2, 4, and 6 in Table 2 mimic the ordinary least squares (OLS) estimates in the columns 1, 3, and 5, respectively, but are estimated using the two-step Heckman selection procedure to control for labor force selection issues arising from excluding individuals with zero earnings from the baseline analysis. As noted earlier, individuals with zero labor earnings in 2004 may be so-called discouraged workers due to past unemployment spells and either are searching for a job with much less intensity than before or have stopped searching completely and have "retired" from the workforce or gone on disability. The Heckman two-step approach first estimates the probability that an individual is in the labor force in 2005 and then conditional on that estimate, analyzes the impact of unemployment duration on the worker's earnings in the second stage. This procedure allows households with zero earnings to be potentially included in the second-stage estimates. ${ }^{9}$

Following Gregory and Jukes (2001), the cumulative duration of any and all past unemployment spells for a worker is the excluded variable used in the first-stage equation to predict the worker's labor force status in the second stage. In addition, the indicator variable for whether a worker has changed industries since his or her last unemployment spell is dropped from the first-stage equation because a worker with zero earnings does not have current industry information. All other explanatory variables from the second stage are included in the first-stage equation. Alternative first-stage specifications that include a measure of local labor demand following Bartik (1993) or the relative local unemployment rate compared to the national average yield very similar results, but have fewer observations.

The estimated unemployment effects in columns 2, 4, and 6 are larger than in the baseline

\footnotetext{
${ }^{9}$ Labor force participation is determined based on an individual's self-reported employment status. Individuals that report they are working, temporarily laid off, or unemployed and looking for work are classified as participating in the labor market, while individuals that report being retired, disabled, or in school are classified as being out of the labor force. Using this metric, roughly 80 percent of household heads in 2005 are classified as being in the labor force. The timing of the employment status data in the PSID is not ideal since the data are recorded in the survey year while the income data cover the prior year. Most of the interviews occur in early 2005, however, so individuals' reported employment status is likely highly correlated with their status in 2004 .
} 
results - especially for the impact of long-duration unemployment. ${ }^{10}$ The rate at which the earnings gap closes with time is also larger though, so the qualitative story that the gap closes after 18 to 20 years is quite similar to the baseline case. The implied earnings losses after 10 years, however, are somewhat larger-about 14 percent for the short-term unemployed and about 48 percent for the long-term unemployed. These wage losses are somewhat larger than the OLS estimates of 9 percent and 32 percent, respectively. These differences are not statistically significant but are broadly consistent with the OLS results potentially being a lower bound on the true unemployment and earnings effect.

Overall, the results that control for selection are similar to the OLS estimates - if not a little stronger - and are nearly identical qualitatively. In addition, the sample restrictions are relaxed for the selection equations to include individuals with unemployment spells since 2000 - those individuals that may be more likely to be discouraged workers - and the results again are very close to the OLS estimates. ${ }^{11}$ In other words, there is little evidence that the estimated relationship between unemployment and future earnings is impacted by selection bias. Gregory and Jukes (2001) and Arulampalam (2001) reach similar conclusions regarding the role of selection in estimating the relationship between unemployment spells and workers' future income.

An additional sample selection concern is that more productive workers are hired first out of unemployment, and thus the remaining long-duration unemployed workers are lower quality workers. Under this scenario the coefficient estimates would pick up a quality effect rather than a duration effect. The wage equations in this paper, however, control for past earnings as a proxy for worker quality. In addition, if the worker quality story was true, then the estimated impact of unemployment on earnings should be minimal at best for short-term unemployed workers. However, a nontrivial wage gap persists for short-duration unemployed workers even 10 years after their job displacement in both the OLS and selection-corrected estimates - a finding that is inconsistent with the worker quality argument.

\section{Robustness and Extensions}

A potential concern is that women's labor market participation could be unduly influencing the results. That is, women tend to have more variable employment histories than men due to their taking time off to have and care for children, among other factors. Table 3 shows estimates of equations 3 and 4 with the sample restricted to males. The results are

\footnotetext{
${ }^{10}$ The point estimates are very close to the OLS estimates if only the nonlinear functional form of the first-stage equation is used for identification.

${ }^{11}$ Unemployed workers in 2004 are still excluded from the analysis.
} 
very similar to the baseline findings although some of the effects are estimated somewhat less precisely due to the smaller sample size. As before, the results are also similar whether or not the estimates account for potential selection bias. It does not appear, therefore, that the inclusion of female-headed households is driving the baseline results. ${ }^{12}$

In addition, an important assumption in the baseline estimates is that the number of years since an individual's most recent unemployment spell (if any) has a linear effect on the worker's earnings returning to what these would have been without the job loss. It is possible, however, that wages catch up in a nonlinear manner. For example, wages may recover more slowly in the initial years after a job displacement and then rebound faster as more time elapses or vice versa. To test this possibility the estimates in Table 4 interact the unemployment spell indicators with a series of dummy variables for the number of years since an individual's last unemployment episode. The dummy variables cover a three to 12 year period since the last unemployment episode (excluded category), a 13 to 18 year period, and 18 years or more. These three bins were chosen to keep relatively equal numbers of workers in each category. ${ }^{13}$ For simplicity, only OLS estimates are reported.

The results in Table 4 are consistent with the baseline findings - earnings fall sharply with a job loss and then rise over time toward what these earnings would have been in the absence of the worker experiencing an unemployment spell. The earnings gap closes after about 18 years - a similar time horizon as in the baseline estimate. ${ }^{14}$ The duration of one's unemployment episode also continues to matter for future earnings - individuals who experience a long-duration unemployment spell are initially much worse off than individuals who endured shorter unemployment spells.

Overall, the estimates suggest that earnings recover in a somewhat nonlinear manner, especially when unemployment duration is taken into account. Wage recovery doubles when the time elapsed since an unemployment episode is 13 to 18 years and 18 years or more, while the implied wage growth between years three and 12 is somewhat slower. Still, it is not clear how much of this doubling in the later years is due to the fact that individuals whose unemployment spell occurred 19 years ago are grouped with individuals that have gone 25 years since their last unemployment episode. Assuming a nonlinear wage recovery rate also does not change the overall implications of the estimates given that unemployment duration

\footnotetext{
${ }^{12}$ The default head of household in the PSID is always a male, so female-headed households are single-parent households unless a male spouse is incapacitated.

${ }^{13}$ Alternative choices with sufficient group sizes yield qualitatively similar results.

${ }^{14}$ The impact effect of job displacement on earnings is smaller than in the baseline results because it includes the excluded category of workers that are three to 12 years removed from their most recent unemployment spell, and thus the estimated coefficients include some wage recovery.
} 
continues to matter for future earnings and the wage gap closes in a similar time frame as the baseline estimates.

This paper's results are also not sensitive to using alternative years for measuring an individual's income. In some instances, the effects are even stronger such as when earnings are measured as of 2000 instead of 2004-past unemployment spells have an even greater negative impact on an individual's subsequent earnings (not shown). ${ }^{15}$

Lastly, Davis and Wachter (2011) show that conditional on job displacement, workers that lose their jobs during a recession are worse off than workers that lose their jobs during an expansionary period. It is not clear though, a priori, that such a wage differential should exist based on the business cycle conditions present when a worker experiences a job loss. During recessions many workers are laid off due to plant closings and other factors tied to the decline in aggregate demand, and these types of job losses are not linked to their individual abilities. In contrast, individuals laid off during expansionary periods may be viewed as lower quality workers since they most likely lost their job for some reason other than an aggregate demand shock. This reasoning would suggest a result opposite the one in Davis and Wachter (2011) — workers laid off during a recession should be better off than workers laid off during an expansion. In this paper, controlling for unemployment spells taking place during a recession has very little impact on the overall results, and there is not a differential earnings effect for workers laid off during a recession versus an expansion (not shown). Perhaps for some workers being laid off during a recession is beneficial while it is detrimental to others, and the effects cancel out across workers and different recession periods. The impact on a workers future earnings of being laid off during the Great Recession versus afterwards could differ, however, given the severity of this recent economic downturn.

\subsection{Other Outcomes}

An advantage of using the PSID for this paper's analysis is that one can trace the impact of unemployment on future outcomes besides an individual's subsequent earnings. Table 5 reports probit estimates (marginal effects) of the impact of past unemployment spells on an individual's homeownership status in 2005. Aside from the use of a probit model, the regression framework is very similar to the baseline approach. The dependent variable is 1 if the individual is a homeowner in 2005 and is 0 otherwise. Controls that matter for earnings - such as whether a worker changes industries - but that likely do not matter for

\footnotetext{
${ }^{15}$ The sample restrictions and variable timing are adjusted accordingly when 2000 earnings or other measures are used.
} 
homeownership are dropped from the analysis, while additional controls are added such as the individual's current (2004) log earnings, lagged financial wealth relative to income, and the total duration (in weeks) of all the household head's past unemployment spells. ${ }^{16}$ As the estimates demonstrate, adding or subtracting these controls does not have much effect on the coefficients of interest.

The results in Table 5 show that after controlling for individuals' income, wealth, past homeownership status, and other factors that likely impact their housing tenure decisions, past unemployment spells have a negative effect on current homeownership status. In particular, individuals that experience an unemployment episode have a roughly 10 to 12 percentage point lower predicted probability of homeownership than individuals without a past job displacement episode (see columns 1 to 3). This homeownership gap closes over time - similar to the earnings gap - as more years elapse since an individual's last unemployment spell. Indeed, the gap is roughly halved after 10 years and is nonexistent after 20 years.

The estimates that divide households based on the duration of their most recent unemployment episode (columns 4 to 6) suggest that homeownership is most impacted for workers who in the past experienced a long-duration unemployment spell. The predicted probability of homeownership is substantially lower for individuals who experienced a long-term unemployment spell compared to those who had a short-term spell - a difference that is statistically significant. In addition, for long-duration unemployed individuals a homeownership gap persists even after 20 years, whereas the negative homeownership effect for short-term unemployed individuals is small and imprecisely estimated.

Overall, the results in Table 5 reinforce the idea that unemployment spells of any length, but especially long-duration unemployment, have negative economic consequences for workers. Examining the impact of unemployment on future homeownership rather than on future earnings is advantageous because individuals with zero income are easily incorporated in the analysis. ${ }^{17}$ Since the estimates control for workers' income, the results further suggest that unemployment spells have a robust economic impact beyond their influence on future earnings. Removing income from the analysis (columns 3 and 6) reduces the fit of the estimated equations but does not have a substantial impact on the results aside from the unemployment effect being slightly larger, as one would expect.

A potential concern with this analysis is that the unemployment indicators are not capturing the impact of job loss but instead the effect of some other unobserved factor on home-

\footnotetext{
${ }^{16}$ Lagged wealth rather than contemporaneous wealth is included because it is arguably more exogenous with respect to an individual's current homeownership status.

${ }^{17}$ Excluding individuals with zero income in 2004 does not noticeably impact the results.
} 
ownership. It is hard, however, to think of an unobserved variable that would be correlated with both past unemployment spells and current homeownership. House prices might be one such variable, but the correlation between house prices and unemployment was strongest during the Great Recession rather than the years covered by the sample used in this paper. The estimates also include state fixed effects, which should absorb any regional differences in house prices or other economic conditions that might impact homeownership. In addition, the estimated impact of financial assets, income, gender, race, and education on homeownership have the expected signs, which is inconsistent with the results being completely spurious.

One reason that past unemployment spells might impact homeownership is that unemployment creates job instability and uncertainty. Households with a recently unemployed head may prefer to rent rather than own until the head finds a new job. Overall, the greater the total number of weeks an individual has been unemployed in the past (total duration), the less likely he or she is to own a home. Renting also allows individuals to be more mobile should an employment opportunity become available that requires relocation. In addition, banks are likely less willing to lend money to an individual with an unstable job history than to someone that has never experienced a job loss.

Past unemployment may also impact wealth accumulation since unemployment spells likely affect an individual's ability to save. Estimates of the relationship between past unemployment and an individual's future wealth are mixed and for the most part imprecisely estimated. There is some evidence that longer duration unemployment spells have a negative impact on an individual's total wealth, conditional on past wealth holdings, income, and other controls used in the baseline estimates. This result, however, is not robust to alternative measures of wealth. ${ }^{18}$

In some instances, the sign of the unemployment effect on wealth is positive, suggesting that past unemployment leads to more wealth accumulation - a finding that is broadly consistent with greater job instability leading to greater buffer stock saving accumulation. Either way, there is not convincing evidence that unemployment spells have an impact on wealth accumulation beyond their effect on earnings. Since earnings and saving are closely related (low-income households have difficulty saving) it may be the case that unemployment does not have an independent effect on wealth accumulation like it does with homeownership. After all, job stability and job history matter for things beyond earnings such as obtaining a mortgage, whereas wealth accumulation is mainly driven by saving behavior and asset price

\footnotetext{
${ }^{18}$ Wealth measures include the log level of real total wealth and real financial assets (stocks, bonds, cash, and retirement accounts), as well as total wealth relative to income and financial assets relative to income. The impact of unemployment on an individual's change in wealth over time was also considered.
} 
fluctuations.

\section{Conclusion}

This paper examined the impact of unemployment duration on individuals' future earnings. Overall, job displacement negatively impacts workers' earnings, and for nearly 20 years their income remains lower than the income of nondisplaced workers. The results further show that unemployment duration matters for these earnings effects - workers unemployed for more than 26 weeks experience a much larger negative income effect and have lower earnings even after 10 or 15 years than those workers that experienced shorter-duration unemployment spells. This finding is inconsistent with the idea that a longer job search leads to better employment matches, and is more consistent with unemployment resulting in human capital (skill) loss or so-called scarring effects. Past unemployment spells also impact individuals' future homeownership status.

The costs associated with persistently high unemployment - especially long-duration unemploymentare an important factor in assessing the efficacy of nontraditional monetary accommodation. Indeed, much debate has occurred regarding the costs and benefits of the Federal Reserve's third round of quantitative easing (QE3). Measuring the impact of QE3 on aggregate demand is difficult since we cannot know how the economy would have fared in the absence of this policy. The unemployment rate, however, has fallen a good bit since QE3 started in September 2012. To the extent that this reduction in unemployment has enabled long-term unemployed workers (or soon-to-be long-term unemployed workers) to obtain new jobs, then the bond-buying program has at least succeeded in limiting the future earnings losses for some individuals.

The sooner long-term unemployed individuals can return to work, the better off they will be in terms of minimizing their future earnings losses. Programs aimed at reducing unemployment, and especially long-duration unemployment, whether through continued quantitative easing or other policies aimed at improving aggregate demand and employment opportunities, could prove beneficial. At the very least, a further reduction in the unemployment rate will not adversely impact the large pool of long-duration unemployed individuals. 


\section{References}

Abraham, Katherine G., and Henry S. Farber. 1987. "Job Duration, Seniority, and Earnings." American Economic Review 77(3): 278-297.

Addison, John T., and Pedro Portugal. 1989. "Job Displacement, Relative Wage Changes, and Duration of Unemployment." Journal of Labor Economics 7(3): 281-302.

Arulampalam, Wiji. 2001. "Is Unemployment Really Scarring? Effects of Unemployment Experience on Wages." The Economic Journal 111(475): 585-606.

Bartik, Timothy J. 1993. "The Effects of Local Labor Demand on Individual Labor Market Outcomes for Different Demographic Groups and the Poor." Working paper 93-23. Kalamzoo, MI: W.E. Upjohn Institute for Employment Research. Available at: http://research.upjohn.org/cgi/viewcontent.cgi?article=1040\&context=up_ workingpapers.

Couch, Kenneth, and Dana Placzek. 2010. "Earnings Losses of Displaced Workers Revisited." American Economic Review 100(1): 572-589.

Davis, Steven J., and Till Von Wachter. 2011. "Recessions and the Costs of Job Loss." Brookings Papers on Economic Activity 1-72.

Fallick, Bruce C. 1996. "A Review of Recent Empirical Literature on Displaced Workers." Industrial and Labor Relations Review 50(1): 5-16.

Gregory, Mary, and Robert Jukes. 2001. "Unemployment and Subsequent Earnings: Estimating Scarring among British Men 1984-94." The Economic Journal 111(475): F607-F625.

Kletzer, Lori Gladstein. 1989. "Returns to Seniority after Permanent Job Loss." American Economic Review 79: 536-543.

Knight, John, and Shi Li. 2006. "Unemployment Duration and Earnings of Re-Employed Workers in Urban China." China Economic Review 17(2): 103-119.

Mincer, Jacob. 1974. Schooling, Experience, and Earnings. New York: National Bureau of Economic Research.

Nickell, Stephen, Patricia Jones, and Glenda Quintini. 2002. "A Picture of Job Insecurity Facing British Men." The Economic Journal 112(476): 1-27. 
Stevens, Ann Huff. 1997. "Persistent Effects of Job Displacement: The Importance of Multiple Job Losses." Journal of Labor Economics 15(1): 165-188. 
Figure 1: Unemployment Duration (Current vs. 2008)

\section{Distribution of Unemployment by Duration (Total Unemployed 100\%)}

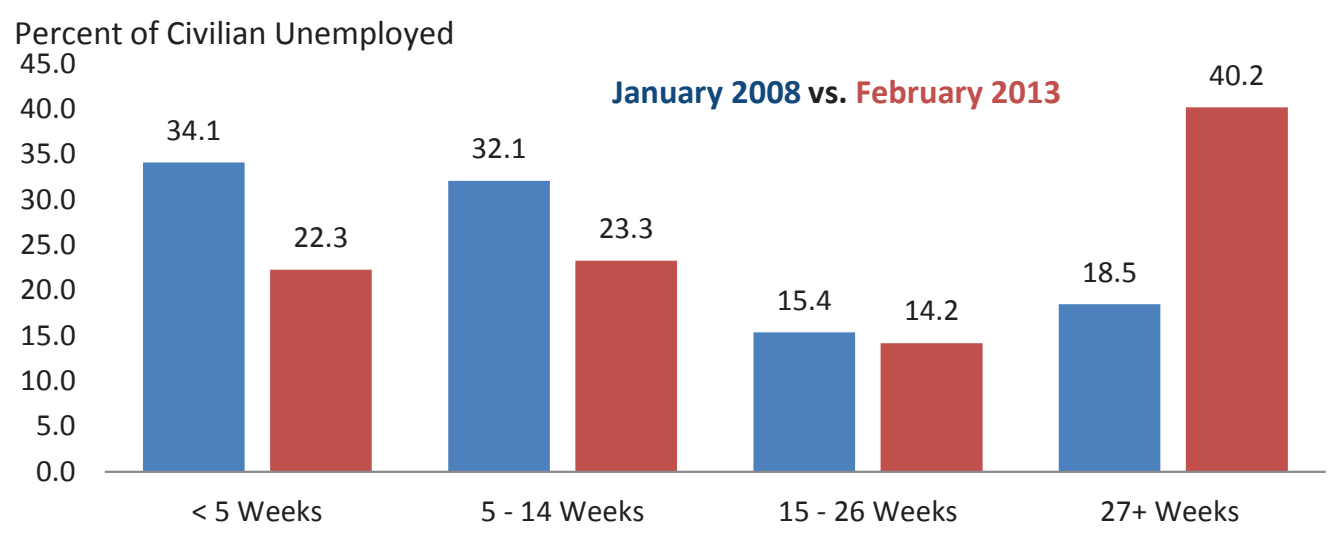

Source: Bureau of Labor Statistics/Haver Analytics. 
TABLE 1: Distribution of Years since Last Unemployment Spell

\begin{tabular}{cccccccc}
\hline \hline Mean & Std. Dev. & p25 & p50 & p75 & Min. & Max. & $\mathbf{N}$ \\
\hline 17.26 & 4.92 & 4 & 13 & 16 & 21 & 28 & 1210 \\
\hline
\end{tabular}


TABle 2: Past Unemployment and Current Earnings (Baseline)

\begin{tabular}{|c|c|c|c|c|c|c|}
\hline & $\begin{array}{l}\text { OLS } \\
(1)\end{array}$ & $\begin{array}{c}\text { With } \\
\text { Selection } \\
\text { Correction } \\
(2)\end{array}$ & $\begin{array}{l}\text { OLS } \\
(3)\end{array}$ & $\begin{array}{c}\text { With } \\
\text { Selection } \\
\text { Correction } \\
(4)\end{array}$ & $\begin{array}{l}\text { OLS } \\
(5)\end{array}$ & $\begin{array}{c}\text { With } \\
\text { Selection } \\
\text { Correction } \\
(6)\end{array}$ \\
\hline Avg. Log Real Earnings (1994-1996) & $\begin{array}{c}0.103^{* * *} \\
(0.017)\end{array}$ & $\begin{array}{c}0.077^{* * *} \\
(0.008)\end{array}$ & $\begin{array}{c}0.103^{* * *} \\
(0.017)\end{array}$ & $\begin{array}{c}0.077^{* * *} \\
(0.008)\end{array}$ & $\begin{array}{c}0.102^{* * *} \\
(0.017)\end{array}$ & $\begin{array}{c}0.077^{* * *} \\
(0.008)\end{array}$ \\
\hline Change Industry $^{a}$ & $\begin{array}{c}-0.098 * * * \\
(0.036)\end{array}$ & $\begin{array}{c}-0.084^{* *} \\
(0.034)\end{array}$ & $\begin{array}{c}-0.095^{* * *} \\
(0.036)\end{array}$ & $\begin{array}{c}-0.083^{* *} \\
(0.034)\end{array}$ & $\begin{array}{c}-0.096^{* * *} \\
(0.036)\end{array}$ & $\begin{array}{c}-0.083^{* *} \\
(0.034)\end{array}$ \\
\hline Unemployment Spell (Last) ${ }^{a}$ & $\begin{array}{c}-0.312^{* * *} \\
(0.108)\end{array}$ & $\begin{array}{c}-0.387^{* * *} \\
(0.109)\end{array}$ & & & & \\
\hline $\mathrm{UE}^{a} \mathrm{x}$ \# Years Since Spell & $\begin{array}{c}0.018^{* * *} \\
(0.006)\end{array}$ & $\begin{array}{c}0.021^{* * *} \\
(0.006)\end{array}$ & & & & \\
\hline Duration of Spell (weeks) & $\begin{array}{c}0.008 \\
(0.006)\end{array}$ & $\begin{array}{c}0.004 \\
(0.006)\end{array}$ & & & $\begin{array}{c}0.008 \\
(0.006)\end{array}$ & $\begin{array}{c}0.004 \\
(0.006)\end{array}$ \\
\hline Duration $^{2}$ (in 100s) & $\begin{array}{c}-0.023^{*} \\
(0.014)\end{array}$ & $\begin{array}{l}-0.015 \\
(0.012)\end{array}$ & & & $\begin{array}{l}-0.018 \\
(0.015)\end{array}$ & $\begin{array}{l}-0.009 \\
(0.014)\end{array}$ \\
\hline Unemployment Spell $\leq 6$ mo. ${ }^{a}$ & & & $\begin{array}{c}-0.248^{* *} \\
(0.113)\end{array}$ & $\begin{array}{c}-0.321^{* * *} \\
(0.111)\end{array}$ & $\begin{array}{c}-0.282^{* *} \\
(0.115)\end{array}$ & $\begin{array}{c}-0.337^{* * *} \\
(0.114)\end{array}$ \\
\hline Unemployment Spell $>6$ mo. $^{a}$ & & & $\begin{array}{c}-0.692^{* *} \\
(0.269)\end{array}$ & $\begin{array}{c}-1.010^{* * *} \\
(0.293)\end{array}$ & $\begin{array}{c}-0.673^{* *} \\
(0.287)\end{array}$ & $\begin{array}{c}-0.994^{* * *} \\
(0.330)\end{array}$ \\
\hline $\mathrm{UE} \leq 6$ mo. $\mathrm{x} \#$ Years Since Spell & & & $\begin{array}{c}0.016^{* * *} \\
(0.006)\end{array}$ & $\begin{array}{c}0.018^{* * *} \\
(0.006)\end{array}$ & $\begin{array}{c}0.016^{* *} \\
(0.006)\end{array}$ & $\begin{array}{c}0.018^{* * *} \\
(0.006)\end{array}$ \\
\hline UE > 6 mo. x \#Years Since Spell & & & $\begin{array}{c}0.037^{* *} \\
(0.016)\end{array}$ & $\begin{array}{c}0.055^{* * *} \\
(0.018)\end{array}$ & $\begin{array}{r}0.035^{* *} \\
(0.016)\end{array}$ & $\begin{array}{c}0.054^{* * *} \\
(0.019)\end{array}$ \\
\hline Total Number of UE Spells & $\begin{array}{l}-0.029 \\
(0.021)\end{array}$ & $\begin{array}{l}-0.030 \\
(0.022)\end{array}$ & $\begin{array}{l}-0.028 \\
(0.021)\end{array}$ & $\begin{array}{c}-0.031 \\
(0.022)\end{array}$ & $\begin{array}{c}-0.028 \\
(0.021)\end{array}$ & $\begin{array}{l}-0.031 \\
(0.022)\end{array}$ \\
\hline Tenure Current Employer & $\begin{array}{c}0.012^{* * *} \\
(0.002)\end{array}$ & $\begin{array}{c}0.008^{* * *} \\
(0.002)\end{array}$ & $\begin{array}{c}0.013^{* * *} \\
(0.002)\end{array}$ & $\begin{array}{c}0.007^{* * *} \\
(0.002)\end{array}$ & $\begin{array}{c}0.013^{* * *} \\
(0.002)\end{array}$ & $\begin{array}{c}0.008^{* * *} \\
(0.002)\end{array}$ \\
\hline \multicolumn{7}{|l|}{ Education: } \\
\hline High School $^{a}$ & $\begin{array}{c}0.202^{* * *} \\
(0.060)\end{array}$ & $\begin{array}{c}0.189^{* * *} \\
(0.048)\end{array}$ & $\begin{array}{c}0.201^{* * *} \\
(0.060)\end{array}$ & $\begin{array}{c}0.190^{* * *} \\
(0.048)\end{array}$ & $\begin{array}{c}0.203^{* * *} \\
(0.060)\end{array}$ & $\begin{array}{c}0.191^{* * *} \\
(0.048)\end{array}$ \\
\hline Some College ${ }^{a}$ & $\begin{array}{c}0.325^{* * *} \\
(0.063)\end{array}$ & $\begin{array}{c}0.306^{* * * *} \\
(0.051)\end{array}$ & $\begin{array}{c}0.329^{* * *} \\
(0.064)\end{array}$ & $\begin{array}{c}0.309^{* * *} \\
(0.051)\end{array}$ & $\begin{array}{c}0.329^{* * *} \\
(0.064)\end{array}$ & $\begin{array}{c}0.309 * * * \\
(0.051)\end{array}$ \\
\hline College or more ${ }^{a}$ & $\begin{array}{c}0.516^{* * *} \\
(0.072)\end{array}$ & $\begin{array}{c}0.483^{* * *} \\
(0.060)\end{array}$ & $\begin{array}{c}0.519^{* * *} \\
(0.073)\end{array}$ & $\begin{array}{c}0.482^{* * *} \\
(0.060)\end{array}$ & $\begin{array}{c}0.520^{* * *} \\
(0.073)\end{array}$ & $\begin{array}{c}0.483^{* * *} \\
(0.060)\end{array}$ \\
\hline Male $\operatorname{Head}^{a}$ & $\begin{array}{c}0.145^{* *} \\
(0.060)\end{array}$ & $\begin{array}{c}0.188^{* * *} \\
(0.051)\end{array}$ & $\begin{array}{c}0.149^{* *} \\
(0.061)\end{array}$ & $\begin{array}{c}0.193^{* * *} \\
(0.051)\end{array}$ & $\begin{array}{c}0.148^{* *} \\
(0.061)\end{array}$ & $\begin{array}{c}0.192^{* * *} \\
(0.051)\end{array}$ \\
\hline Family Size & $\begin{array}{c}0.057^{* * *} \\
(0.014)\end{array}$ & $\begin{array}{c}0.040^{* * *} \\
(0.013)\end{array}$ & $\begin{array}{c}0.055^{* * *} \\
(0.014)\end{array}$ & $\begin{array}{c}0.039^{* * *} \\
(0.013)\end{array}$ & $\begin{array}{c}0.055^{* * *} \\
(0.014)\end{array}$ & $\begin{array}{c}0.039^{* * *} \\
(0.013)\end{array}$ \\
\hline$\lambda$ & & $\begin{array}{c}-0.21 \\
(0.13)\end{array}$ & & $\begin{array}{c}-0.31 \\
(0.13)\end{array}$ & & $\begin{array}{l}-0.30 \\
(0.13)\end{array}$ \\
\hline $\begin{array}{l}\mathrm{N} \\
\text { Adjusted } \mathrm{R}^{2}\end{array}$ & $\begin{array}{l}2454 \\
0.38\end{array}$ & 2510 & $\begin{array}{l}2454 \\
0.38\end{array}$ & 2510 & $\begin{array}{l}2454 \\
0.38\end{array}$ & 2510 \\
\hline
\end{tabular}

Notes: ${ }^{a} 0 / 1$ indicator variable. Earnings (the dependent variable) are measured as labor income for the household head in 2004. An individual's last unemployment spell is used in the estimation when he or she has multiple spells prior to 2004 . The sample is restricted to individuals whose most recent unemployment spell is in 2001 or earlier, and who are between 25 and 65 years old in 2004. The OLS estimates (nonselection adjusted estimates) in columns 1, 3, and 5 further restrict the sample to individuals with positive earnings in 2004. The first-stage equation used in the two-step estimation in columns 2, 4, and 6 predicts an individual's labor force participation and relies on the nonlinearity of the estimation approach for identification-including all the variables from the second-stage except the change in industry indicator. OLS and two-step estimates also include state, industry, and occupation fixed effects, as well as controls for the the individual's race (black or otherwise), the individual's marital status, the total number of jobs worked in 2004, and a cubic term for the age of the household head. Robust standard errors: ${ }^{* * *}$ significant at the 1-percent level, ${ }^{* *}$ significant at the 5 -percent level, ${ }^{*}$ significant at the 10 -percent level. 
TABLE 3: Past Unemployment and Current Earnings (Males Only)

\begin{tabular}{|c|c|c|c|c|c|c|}
\hline & $\begin{array}{l}\text { OLS } \\
(1)\end{array}$ & $\begin{array}{c}\text { With } \\
\text { Selection } \\
\text { Correction } \\
(2)\end{array}$ & $\begin{array}{c}\text { OLS } \\
(3)\end{array}$ & $\begin{array}{c}\text { With } \\
\text { Selection } \\
\text { Correction } \\
(4)\end{array}$ & $\begin{array}{c}\text { OLS } \\
(5)\end{array}$ & $\begin{array}{c}\text { With } \\
\text { Selection } \\
\text { Correction } \\
(6)\end{array}$ \\
\hline Avg. Log Real Earnings (1994-1996) & $\begin{array}{c}0.090^{* * *} \\
(0.021)\end{array}$ & $\begin{array}{c}0.076^{* * *} \\
(0.011)\end{array}$ & $\begin{array}{c}0.092^{* * *} \\
(0.021)\end{array}$ & $\begin{array}{c}0.077^{* * *} \\
(0.010)\end{array}$ & $\begin{array}{c}0.090^{* * *} \\
(0.021)\end{array}$ & $\begin{array}{c}0.076^{* * *} \\
(0.011)\end{array}$ \\
\hline Change Industry $^{a}$ & $\begin{array}{c}-0.101^{* *} \\
(0.041)\end{array}$ & $\begin{array}{c}-0.073^{*} \\
(0.040)\end{array}$ & $\begin{array}{c}-0.099^{* *} \\
(0.040)\end{array}$ & $\begin{array}{r}-0.074^{*} \\
(0.040)\end{array}$ & $\begin{array}{c}-0.100^{* *} \\
(0.040)\end{array}$ & $\begin{array}{r}-0.074^{*} \\
(0.040)\end{array}$ \\
\hline Unemployment Spell (Last) ${ }^{a}$ & $\begin{array}{c}-0.339^{* * *} \\
(0.129)\end{array}$ & $\begin{array}{c}-0.381^{* * *} \\
(0.129)\end{array}$ & & & & \\
\hline $\mathrm{UE}^{a} \mathrm{x}$ \# Years Since Spell & $\begin{array}{c}0.016^{* *} \\
(0.007)\end{array}$ & $\begin{array}{c}0.019^{* * *} \\
(0.007)\end{array}$ & & & & \\
\hline Duration of Spell (weeks) & $\begin{array}{l}0.011 \\
(0.007)\end{array}$ & $\begin{array}{c}0.006 \\
(0.007)\end{array}$ & & & $\begin{array}{c}0.011 \\
(0.007)\end{array}$ & $\begin{array}{c}0.006 \\
(0.007)\end{array}$ \\
\hline Duration $^{2}$ (in 100s) & $\begin{array}{l}-0.033^{*} \\
(0.017)\end{array}$ & $\begin{array}{l}-0.020 \\
(0.016)\end{array}$ & & & $\begin{array}{l}-0.032 \\
(0.020)\end{array}$ & $\begin{array}{l}-0.019 \\
(0.018)\end{array}$ \\
\hline Unemployment Spell $\leq 6$ mo. $^{a}$ & & & $\begin{array}{c}-0.286^{* *} \\
(0.136)\end{array}$ & $\begin{array}{c}-0.339^{* * *} \\
(0.130)\end{array}$ & $\begin{array}{c}-0.331^{* *} \\
(0.137)\end{array}$ & $\begin{array}{c}-0.360^{* * *} \\
(0.134)\end{array}$ \\
\hline Unemployment Spell $>6$ mo. $^{a}$ & & & $\begin{array}{c}-0.542^{*} \\
(0.325)\end{array}$ & $\begin{array}{c}-0.726^{* *} \\
(0.370)\end{array}$ & $\begin{array}{l}-0.430 \\
(0.366)\end{array}$ & $\begin{array}{l}-0.635 \\
(0.412)\end{array}$ \\
\hline $\mathrm{UE} \leq 6$ mo. $\mathrm{x} \#$ Years Since Spell & & & $\begin{array}{c}0.016^{* *} \\
(0.007)\end{array}$ & $\begin{array}{c}0.018^{* *} \\
(0.007)\end{array}$ & $\begin{array}{c}0.015^{* *} \\
(0.007)\end{array}$ & $\begin{array}{c}0.018^{* *} \\
(0.007)\end{array}$ \\
\hline UE > 6 mo. x \#Years Since Spell & & & $\begin{array}{c}0.025 \\
(0.020)\end{array}$ & $\begin{array}{c}0.037 \\
(0.023)\end{array}$ & $\begin{array}{c}0.020 \\
(0.020)\end{array}$ & $\begin{array}{c}0.035 \\
(0.023)\end{array}$ \\
\hline Total Number of UE Spells & $\begin{array}{l}-0.022 \\
(0.025)\end{array}$ & $\begin{array}{l}-0.022 \\
(0.026)\end{array}$ & $\begin{array}{l}-0.023 \\
(0.025)\end{array}$ & $\begin{array}{l}-0.023 \\
(0.026)\end{array}$ & $\begin{array}{l}-0.022 \\
(0.025)\end{array}$ & $\begin{array}{c}-0.022 \\
(0.026)\end{array}$ \\
\hline Tenure Current Employer & $\begin{array}{c}0.011^{* * *} * \\
(0.002)\end{array}$ & $\begin{array}{c}0.008^{* * *} \\
(0.002)\end{array}$ & $\begin{array}{c}0.011^{* * *} \\
(0.002)\end{array}$ & $\begin{array}{c}0.008^{* * *} \\
(0.002)\end{array}$ & $\begin{array}{c}0.011^{* * *} \\
(0.002)\end{array}$ & $\begin{array}{c}0.008^{* * *} \\
(0.002)\end{array}$ \\
\hline \multicolumn{7}{|l|}{ Education: } \\
\hline High School $^{a}$ & $\begin{array}{c}0.207^{* * *} \\
(0.073)\end{array}$ & $\begin{array}{c}0.193^{* * *} \\
(0.058)\end{array}$ & $\begin{array}{c}0.206^{* * *} \\
(0.073)\end{array}$ & $\begin{array}{c}0.192^{* * *} \\
(0.058)\end{array}$ & $\begin{array}{c}0.207^{* * *} \\
(0.073)\end{array}$ & $\begin{array}{c}0.194^{* * *} \\
(0.058)\end{array}$ \\
\hline Some College ${ }^{a}$ & $\begin{array}{c}0.314^{* * *} \\
(0.079)\end{array}$ & $\begin{array}{c}0.314^{* * *} \\
(0.063)\end{array}$ & $\begin{array}{c}0.321^{* * *} \\
(0.080)\end{array}$ & $\begin{array}{c}0.315^{* * *} \\
(0.063)\end{array}$ & $\begin{array}{c}0.319^{* * *} \\
(0.079)\end{array}$ & $\begin{array}{c}0.314^{* * *} * \\
(0.063)\end{array}$ \\
\hline College or more ${ }^{a}$ & $\begin{array}{c}0.539^{* * * *} \\
(0.087)\end{array}$ & $\begin{array}{c}0.515^{* * *} \\
(0.070)\end{array}$ & $\begin{array}{c}0.544^{* * *} \\
(0.088)\end{array}$ & $\begin{array}{c}0.514^{* * *} \\
(0.070)\end{array}$ & $\begin{array}{c}0.544^{* * *} \\
(0.088)\end{array}$ & $\begin{array}{c}0.515^{* * *} \\
(0.070)\end{array}$ \\
\hline Family Size & $\begin{array}{c}0.068^{* * *} \\
(0.017) \\
\end{array}$ & $\begin{array}{c}0.057^{* * * *} \\
(0.015) \\
\end{array}$ & $\begin{array}{c}0.067^{* * * *} \\
(0.017)\end{array}$ & $\begin{array}{c}0.056^{* * *} \\
(0.015) \\
\end{array}$ & $\begin{array}{c}0.067^{* * *} \\
(0.017) \\
\end{array}$ & $\begin{array}{c}0.057^{* * *} \\
(0.015) \\
\end{array}$ \\
\hline$\lambda$ & & $\begin{array}{c}0.10 \\
(0.16)\end{array}$ & & $\begin{array}{c}0.04 \\
(0.16)\end{array}$ & & $\begin{array}{c}0.05 \\
(0.16)\end{array}$ \\
\hline $\begin{array}{l}\mathrm{N} \\
\text { Adjusted } \mathrm{R}^{2}\end{array}$ & $\begin{array}{l}1945 \\
0.31\end{array}$ & 1972 & $\begin{array}{l}1945 \\
0.31\end{array}$ & 1972 & $\begin{array}{l}1945 \\
0.31\end{array}$ & 1972 \\
\hline
\end{tabular}

Notes: ${ }^{a} 0 / 1$ indicator variable. Earnings (the dependent variable) are measured as labor income for the household head in 2004. An individual's last unemployment spell is used in the estimation when he or she has multiple spells prior to 2004 . The sample is restricted to males whose most recent unemployment spell is in 2001 or earlier, and who are between 25 and 65 years old in 2004. The OLS estimates (nonselection adjusted estimates) in columns 1, 3, and 5 further restrict the sample to individuals with positive earnings in 2004. The first-stage equation used in the two-step estimation in columns 2, 4, and 6 predicts individual's labor force participation and relies on the nonlinearity of the estimation approach for identification-including all the variables from the second-stage except the change in industry indicator. OLS and two-step estimates also include state, industry, and occupation fixed effects, as well as controls for the individual's race (black or otherwise), the individual's marital status, the total number of jobs worked in 2004, and a cubic term for the age of the household head. Robust standard errors: *** significant at the 1-percent level, ${ }^{* *}$ significant at the 5 -percent level, ${ }^{*}$ significant at the 10 -percent level. 
TABle 4: Past Unemployment and Current Earnings (Nonlinear Earnings Catch Up)

\begin{tabular}{|c|c|c|c|}
\hline & $\begin{array}{c}\text { OLS } \\
(1)\end{array}$ & $\begin{array}{c}\text { OLS } \\
(2)\end{array}$ & $\begin{array}{c}\text { OLS } \\
(3)\end{array}$ \\
\hline Avg. Log Real Earnings (1994-1996) & $\begin{array}{c}0.094^{* * *} \\
(0.016)\end{array}$ & $\begin{array}{c}0.094^{* * *} \\
(0.016)\end{array}$ & $\begin{array}{c}0.094^{* * *} \\
(0.016)\end{array}$ \\
\hline Change Industry $^{a}$ & $\begin{array}{c}-0.106^{* * *} \\
(0.036)\end{array}$ & $\begin{array}{c}-0.105^{* * *} * \\
(0.036)\end{array}$ & $\begin{array}{c}-0.106 * * * \\
(0.036)\end{array}$ \\
\hline Unemployment Spell (Last) ${ }^{a}$ & $\begin{array}{l}-0.101 \\
(0.067)\end{array}$ & & \\
\hline $\mathrm{UE}^{a} \times \mathrm{I}(13 \text {-to-18 yrs since spell })^{b}$ & $\begin{array}{c}0.065 \\
(0.063)\end{array}$ & & \\
\hline $\mathrm{UE}^{a} \times \mathrm{I}(18+\text { yrs since spell })^{c}$ & $\begin{array}{c}0.154^{* *} \\
(0.063)\end{array}$ & & \\
\hline Duration of Spell (weeks) & $\begin{array}{c}0.008 \\
(0.006)\end{array}$ & & $\begin{array}{c}0.007 \\
(0.006)\end{array}$ \\
\hline Duration $^{2}$ (in 100s) & $\begin{array}{c}-0.022^{*} \\
(0.013)\end{array}$ & & $\begin{array}{l}-0.015 \\
(0.015)\end{array}$ \\
\hline Unemployment Spell $\leq 6$ mo. $^{a}$ & & $\begin{array}{l}-0.038 \\
(0.062)\end{array}$ & $\begin{array}{l}-0.083 \\
(0.070)\end{array}$ \\
\hline Unemployment Spell > 6 mo. $^{a}$ & & $\begin{array}{c}-0.279^{* *} \\
(0.114)\end{array}$ & $\begin{array}{c}-0.310^{*} \\
(0.173)\end{array}$ \\
\hline $\mathrm{UE} \leq 6$ mo. $\mathrm{x} \mathrm{I}(13 \text {-to-18 yrs since spell })^{b}$ & & $\begin{array}{c}0.049 \\
(0.068)\end{array}$ & $\begin{array}{c}0.049 \\
(0.068)\end{array}$ \\
\hline $\mathrm{UE} \leq 6$ mo. $\mathrm{x} \mathrm{I}(18+\text { yrs since spell })^{c}$ & & $\begin{array}{c}0.112 \\
(0.069)\end{array}$ & $\begin{array}{c}0.110 \\
(0.070)\end{array}$ \\
\hline $\mathrm{UE}>6$ mo. $\mathrm{x} \mathrm{I}(13 \text {-to-18 yrs since spell })^{b}$ & & $\begin{array}{c}0.149 \\
(0.151)\end{array}$ & $\begin{array}{c}0.137 \\
(0.156)\end{array}$ \\
\hline $\mathrm{UE}>6$ mo. $\mathrm{x} \mathrm{I}(18+\text { yrs since spell })^{c}$ & & $\begin{array}{c}0.457^{* * *} \\
(0.148)\end{array}$ & $\begin{array}{c}0.440^{* * *} \\
(0.145)\end{array}$ \\
\hline Total Number of UE Spells & $\begin{array}{c}-0.033 \\
(0.023)\end{array}$ & $\begin{array}{l}-0.034 \\
(0.023)\end{array}$ & $\begin{array}{l}-0.034 \\
(0.023)\end{array}$ \\
\hline Tenure Current Employer & $\begin{array}{c}0.013^{* * *} \\
(0.002)\end{array}$ & $\begin{array}{c}0.013^{* * *} \\
(0.002)\end{array}$ & $\begin{array}{c}0.013^{* * *} \\
(0.002)\end{array}$ \\
\hline $\mathrm{N}$ & 2489 & 2489 & 2489 \\
\hline Adjusted $\mathrm{R}^{2}$ & 0.76 & 0.76 & 0.76 \\
\hline
\end{tabular}

Notes: ${ }^{a} 0 / 1$ indicator variable. ${ }^{b} 0 / 1$ indicator for whether it has been 13 -to- 18 years since the individuals unemployment spell. ${ }^{c} 0 / 1$ indicator for whether it has been more than 18 years since the individuals unemployment spell, excluded category is 3-to-12 years since. Earnings (the dependent variable) are measured as labor income for the household head in 2004. An individual's last unemployment spell is used in the estimation when he or she has multiple spells prior to 2004. The sample is restricted to individuals whose most recent unemployment spell is in 2001 or earlier, who are between 25 and 65 years in 2004, and have positive earnings. the estimates also include state, industry, and occupation fixed effects, as well as controls for the individual's race (black or otherwise) the individual's marital status, the total number of jobs worked in 2004, and a cubic term for the age of the household head. Robust standard errors: ${ }^{* * *}$ significant at the 1 -percent level, ** significant at the 5-percent level, * significant at the 10-percent level. 
TABle 5: Past Unemployment Effects on Current (2005) Homeownership

\begin{tabular}{|c|c|c|c|c|c|c|}
\hline & $(1)$ & $(2)$ & $(3)$ & $(4)$ & $(5)$ & $(6)$ \\
\hline Homeowner $(1994)^{a}$ & $\begin{array}{c}0.233^{* * *} \\
(0.020)\end{array}$ & $\begin{array}{c}0.200^{* * *} \\
(0.020)\end{array}$ & $\begin{array}{c}0.225^{* * *} \\
(0.017)\end{array}$ & $\begin{array}{c}0.236^{* * *} \\
(0.020)\end{array}$ & $\begin{array}{c}0.204^{* * *} \\
(0.020)\end{array}$ & $\begin{array}{c}0.230^{* * *} \\
(0.017)\end{array}$ \\
\hline Log Income (2004) & $\begin{array}{c}0.039^{* * *} \\
(0.010)\end{array}$ & $\begin{array}{c}0.033^{* * *} \\
(0.010)\end{array}$ & & $\begin{array}{c}0.039^{* * *} \\
(0.010)\end{array}$ & $\begin{array}{c}0.033^{* * *} \\
(0.010)\end{array}$ & \\
\hline Avg. Log Income (1994-1996) & $\begin{array}{c}0.010^{* * *} \\
(0.004)\end{array}$ & $\begin{array}{c}0.013^{* * *} \\
(0.004)\end{array}$ & & $\begin{array}{c}0.010^{* * *} \\
(0.004)\end{array}$ & $\begin{array}{c}0.013^{* * *} \\
(0.004)\end{array}$ & \\
\hline Fin. Assets Rel. Income (1999) & $\begin{array}{c}0.031^{* *} \\
(0.012)\end{array}$ & & $\begin{array}{c}0.044^{* * * *} \\
(0.013)\end{array}$ & $\begin{array}{c}0.030^{* *} \\
(0.012)\end{array}$ & & $\begin{array}{c}0.043^{* * *} \\
(0.013)\end{array}$ \\
\hline Tot. Wealth Rel. Income (1999) & & $\begin{array}{c}0.032^{* * * *} \\
(0.007)\end{array}$ & & & $\begin{array}{c}0.031^{* * * *} \\
(0.007)\end{array}$ & \\
\hline Unemployment Spell (Last) $^{a}$ & $\begin{array}{c}-0.105^{*} \\
(0.055)\end{array}$ & $\begin{array}{l}-0.079 \\
(0.052)\end{array}$ & $\begin{array}{c}-0.138^{* *} \\
(0.060)\end{array}$ & & & \\
\hline $\mathrm{UE}^{a}$ x Years Since Spell & $\begin{array}{c}0.004 \\
(0.003)\end{array}$ & $\begin{array}{c}0.003 \\
(0.003)\end{array}$ & $\begin{array}{c}0.004 \\
(0.003)\end{array}$ & & & \\
\hline Last UE Spell $\leq 6$ mo. $^{a}$ & & & & $\begin{array}{l}-0.059 \\
(0.057)\end{array}$ & $\begin{array}{l}-0.041 \\
(0.054)\end{array}$ & $\begin{array}{c}-0.106^{*} \\
(0.062)\end{array}$ \\
\hline Last UE Spell > 6 mo. $^{a}$ & & & & $\begin{array}{c}-0.704^{* * *} \\
(0.171)\end{array}$ & $\begin{array}{c}-0.602^{* * *} \\
(0.224)\end{array}$ & $\begin{array}{c}-0.645^{* * *} \\
(0.176)\end{array}$ \\
\hline $\mathrm{UE} \leq 6$ mo. $\mathrm{x}$ Years Since Spell & & & & $\begin{array}{c}0.002 \\
(0.003)\end{array}$ & $\begin{array}{c}0.001 \\
(0.003)\end{array}$ & $\begin{array}{c}0.003 \\
(0.003)\end{array}$ \\
\hline $\mathrm{UE}>6$ mo. $\mathrm{x}$ Years Since Spell & & & & $\begin{array}{c}0.025^{* * *} \\
(0.008)\end{array}$ & $\begin{array}{c}0.020^{* * *} \\
(0.008)\end{array}$ & $\begin{array}{c}0.025^{* * *} \\
(0.009)\end{array}$ \\
\hline Total Number of UE Spells & $\begin{array}{c}0.007 \\
(0.012)\end{array}$ & $\begin{array}{c}0.005 \\
(0.012)\end{array}$ & $\begin{array}{c}0.004 \\
(0.014)\end{array}$ & $\begin{array}{c}0.005 \\
(0.012)\end{array}$ & $\begin{array}{c}0.004 \\
(0.012)\end{array}$ & $\begin{array}{c}-0.008 \\
(0.012)\end{array}$ \\
\hline Duration of Spell (weeks) & $\begin{array}{l}-0.002 \\
(0.003)\end{array}$ & $\begin{array}{l}-0.002 \\
(0.003)\end{array}$ & $\begin{array}{l}-0.001 \\
(0.003)\end{array}$ & $\begin{array}{l}-0.003 \\
(0.003)\end{array}$ & $\begin{array}{l}-0.002 \\
(0.003)\end{array}$ & $\begin{array}{l}-0.002 \\
(0.003)\end{array}$ \\
\hline Duration $^{2}$ (in 100s) & $\begin{array}{c}0.002 \\
(0.006)\end{array}$ & $\begin{array}{c}0.000 \\
(0.006)\end{array}$ & $\begin{array}{l}-0.003 \\
(0.007)\end{array}$ & $\begin{array}{c}0.004 \\
(0.007)\end{array}$ & $\begin{array}{c}0.002 \\
(0.007)\end{array}$ & $\begin{array}{l}-0.000 \\
(0.007)\end{array}$ \\
\hline Total Duration all UE Spells & $\begin{array}{l}-0.000 \\
(0.000)\end{array}$ & $\begin{array}{l}-0.000 \\
(0.000)\end{array}$ & $\begin{array}{c}-0.001^{*} \\
(0.000)\end{array}$ & $\begin{array}{l}-0.000 \\
(0.000)\end{array}$ & $\begin{array}{l}-0.000 \\
(0.000)\end{array}$ & \\
\hline \multicolumn{7}{|l|}{ Education: } \\
\hline High School $^{a}$ & $\begin{array}{c}0.050^{* *} \\
(0.021)\end{array}$ & $\begin{array}{c}0.032 \\
(0.020)\end{array}$ & $\begin{array}{c}0.075^{* * *} \\
(0.019)\end{array}$ & $\begin{array}{c}0.052^{* *} \\
(0.021)\end{array}$ & $\begin{array}{c}0.033 \\
(0.020)\end{array}$ & $\begin{array}{c}0.076^{* * *} \\
(0.019)\end{array}$ \\
\hline Some College ${ }^{a}$ & $\begin{array}{c}0.050^{* *} \\
(0.022)\end{array}$ & $\begin{array}{c}0.030 \\
(0.022)\end{array}$ & $\begin{array}{c}0.072^{* * *} \\
(0.020)\end{array}$ & $\begin{array}{c}0.051^{* *} \\
(0.022)\end{array}$ & $\begin{array}{c}0.031 \\
(0.022)\end{array}$ & $\begin{array}{c}0.073^{* * *} \\
(0.020)\end{array}$ \\
\hline College or more ${ }^{a}$ & $\begin{array}{c}0.095^{* * *} \\
(0.023)\end{array}$ & $\begin{array}{c}0.084^{* * *} \\
(0.022)\end{array}$ & $\begin{array}{c}0.128^{* * *} \\
(0.020)\end{array}$ & $\begin{array}{c}0.096^{* * *} \\
(0.022)\end{array}$ & $\begin{array}{c}0.084^{* * *} \\
(0.022)\end{array}$ & $\begin{array}{c}0.129 * * * \\
(0.020)\end{array}$ \\
\hline Male $^{a}$ & $\begin{array}{c}0.080^{* * *} \\
(0.025) \\
\end{array}$ & $\begin{array}{c}0.065^{* * *} \\
(0.024) \\
\end{array}$ & $\begin{array}{c}0.142^{* * *} \\
(0.024) \\
\end{array}$ & $\begin{array}{c}0.081^{* * *} \\
(0.025) \\
\end{array}$ & $\begin{array}{c}0.066^{* * *} \\
(0.024) \\
\end{array}$ & $\begin{array}{c}0.142^{* * *} \\
(0.024) \\
\end{array}$ \\
\hline $\mathrm{N}$ & 2549 & 2495 & 3175 & 2549 & 2495 & 3175 \\
\hline Pseudo- $\mathrm{R}^{2}$ & 0.33 & 0.34 & 0.27 & 0.33 & 0.34 & 0.27 \\
\hline
\end{tabular}

Notes: The table reports marginal effects. The dependant variable takes a value of 1 if the household head is a homeowner in 2005 , and is 0 otherwise. ${ }^{a} 0 / 1$ indicator variable. An unemployment spell less than or equal to six-months is defined as any reported past unemployment period of one week or more but no longer than 26 weeks. an unemployment spell greater than six months is defined as any past spell greater than 26 weeks. the last spell is defined as the household head's most recent unemployment spell prior to 2004. Individuals reporting an unemployment spell after 2001 are excluded from the analysis. Estimates also include state, industry, and occupation fixed effects, as well as controls for race (black or otherwise), and a cubic term for the age of the household head. Robust standard errors: *** significant at the 1-percent level, ${ }^{* *}$ significant at the 5-percent level, * significant at the 10 -percent level. 


\section{A Appendix}

TABle A.1: OLS Sample Restrictions: Contributors

\begin{tabular}{lc}
\hline & $\begin{array}{c}\text { Remaining } \\
\text { Sample Size }\end{array}$ \\
\hline Initial 2005 Sample & 8,002 \\
Restrictions & \\
2004 Income $>0$ & 6,358 \\
Age 25 to 65 years & 5,411 \\
3 or more yrs. since last spell & 4,831 \\
Nonmissing past income & 2,899 \\
Nonmissing education info & 2,814 \\
Nonmissing industry/occupation data & 2,804 \\
Nonmissing worker tenure data & 2,767 \\
Nonmissing industry change data & 2,467 \\
\hline
\end{tabular}


TABle A.2: First-Stage Selection Equations (Baseline)

\begin{tabular}{|c|c|c|c|}
\hline & $\begin{array}{c}\text { With } \\
\text { Selection } \\
\text { Correction } \\
(2)\end{array}$ & $\begin{array}{c}\text { With } \\
\text { Selection } \\
\text { Correction } \\
\text { (4) }\end{array}$ & $\begin{array}{c}\text { With } \\
\text { Selection } \\
\text { Correction } \\
(6)\end{array}$ \\
\hline Avg. Log Real Earnings (1994-1996) & $\begin{array}{c}0.014 \\
(0.028)\end{array}$ & $\begin{array}{c}0.025 \\
(0.026)\end{array}$ & $\begin{array}{c}0.024 \\
(0.027)\end{array}$ \\
\hline Unemployment Spell (Last) $^{a}$ & $\begin{array}{c}1.303^{*} \\
(0.779)\end{array}$ & & \\
\hline $\mathrm{UE}^{a} \mathrm{x}$ \# Years Since Spell & $\begin{array}{l}-0.050 \\
(0.039)\end{array}$ & & \\
\hline Duration of Spell (weeks) & $\begin{array}{l}-0.016 \\
(0.033)\end{array}$ & & $\begin{array}{l}-0.015 \\
(0.032)\end{array}$ \\
\hline Duration $^{2}$ (in 100s) & $\begin{array}{c}0.012 \\
(0.062)\end{array}$ & & $\begin{array}{c}0.002 \\
(0.075)\end{array}$ \\
\hline Unemployment Spell $\leq 6$ mo. $^{a}$ & & $\begin{array}{c}0.980 \\
(0.718)\end{array}$ & $\begin{array}{c}1.158 \\
(0.768)\end{array}$ \\
\hline Unemployment Spell $>6$ mo. $^{a}$ & & $\begin{array}{c}4.173^{* *} \\
(1.820)\end{array}$ & $\begin{array}{c}4.840^{* *} \\
(2.086)\end{array}$ \\
\hline $\mathrm{UE} \leq 6$ mo. $\mathrm{x} \#$ Years Since Spell & & $\begin{array}{l}-0.043 \\
(0.039)\end{array}$ & $\begin{array}{l}-0.043 \\
(0.040)\end{array}$ \\
\hline UE $>6$ mo. $x$ \#Years Since Spell & & $\begin{array}{c}-0.253^{* *} \\
(0.112)\end{array}$ & $\begin{array}{c}-0.258^{* *} \\
(0.113)\end{array}$ \\
\hline Total Number of UE Spells & $\begin{array}{c}-0.032 \\
(0.159)\end{array}$ & $\begin{array}{c}0.019 \\
(0.148)\end{array}$ & $\begin{array}{c}-0.001 \\
(0.150)\end{array}$ \\
\hline Tenure Current Employer & $\begin{array}{c}0.965^{* * *} \\
(0.146)\end{array}$ & $\begin{array}{c}0.973^{* * *} \\
(0.149)\end{array}$ & $\begin{array}{c}0.975^{* * *} \\
(0.150)\end{array}$ \\
\hline \multicolumn{4}{|l|}{ Education: } \\
\hline High School $^{a}$ & $\begin{array}{l}-0.189 \\
(0.244)\end{array}$ & $\begin{array}{l}-0.216 \\
(0.235)\end{array}$ & $\begin{array}{l}-0.224 \\
(0.236)\end{array}$ \\
\hline Some College ${ }^{a}$ & $\begin{array}{l}-0.109 \\
(0.282)\end{array}$ & $\begin{array}{c}-0.057 \\
(0.267)\end{array}$ & $\begin{array}{l}-0.065 \\
(0.268)\end{array}$ \\
\hline College or more ${ }^{a}$ & $\begin{array}{c}0.055 \\
(0.360)\end{array}$ & $\begin{array}{c}0.262 \\
(0.350)\end{array}$ & $\begin{array}{c}0.249 \\
(0.352)\end{array}$ \\
\hline Male Head ${ }^{a}$ & $\begin{array}{l}-0.079 \\
(0.272)\end{array}$ & $\begin{array}{c}-0.139 \\
(0.260)\end{array}$ & $\begin{array}{l}-0.148 \\
(0.262)\end{array}$ \\
\hline Family Size & $\begin{array}{c}0.152^{* *} \\
(0.070)\end{array}$ & $\begin{array}{c}0.151^{* *} \\
(0.069)\end{array}$ & $\begin{array}{c}0.153^{* *} \\
(0.069)\end{array}$ \\
\hline $\mathrm{N}$ & 2510 & 2510 & 2510 \\
\hline
\end{tabular}

Notes: The table reports first-stage estimates for baseline Heckman-selection estimates (columns 2,4 , and 6 of baseline results). ${ }^{a} 0 / 1$ indicator variable. The dependent variable is a $0 / 1$ indicator for whether the household reports being in the labor force in 2005 . The sample is restricted to individuals whose most recent unemployment spell is in 2001 or earlier, and who are between 25 and 65 years old in 2004. Estimates also include state, industry, and occupation fixed effects, as well as controls for the individual's race (black or otherwise), the individual's marital status, the total number of jobs worked in 2004, and a cubic term for the age of the household head. Robust standard errors: *** significant at the 1-percent level, ** significant at the 5-percent level, * significant at the 10-percent level. 
TABle A.3: Summary Statistics (Baseline Variables)

\begin{tabular}{|c|c|c|c|c|c|}
\hline Variable & Mean & Std. Dev. & Min. & Max. & $\mathbf{N}$ \\
\hline Age of Household Head & 44.67 & 10.4 & 26 & 65 & 4807 \\
\hline Male Heads (\%) & 0.77 & 0.42 & 0 & 1 & 4807 \\
\hline Married (\%) & 0.57 & 0.5 & 0 & 1 & 4807 \\
\hline Family Size & 2.63 & 1.42 & 1 & 10 & 4807 \\
\hline Black $(\%)$ & 0.04 & 0.19 & 0 & 1 & 4807 \\
\hline Number of Jobs in 2005 & 1.31 & 0.6 & 0 & 8 & 4807 \\
\hline Log of Real Labor Income in 2004 & 10.45 & 0.95 & 0.65 & 14.73 & 4807 \\
\hline Avg. Log of Real Labor Income 1994-1996 & 10.11 & 1.78 & 0 & 13.39 & 2884 \\
\hline Changed Industry (\%) & 0.66 & 0.47 & 0 & 1 & 2631 \\
\hline Tenure at Current Employer (years) & 7.98 & 8.85 & 0 & 43 & 4732 \\
\hline Any Past Unemployment Spell (\%) & 0.28 & 0.45 & 0 & 1 & 4807 \\
\hline Long Duration UE Spell (\%) & 0.12 & 0.32 & 0 & 1 & 4807 \\
\hline Short Duration UE Spell (\%) & 0.17 & 0.37 & 0 & 1 & 4807 \\
\hline $\begin{array}{l}\text { Total Number of Unemployment Spells }{ }^{a} \\
\text { Duration of Unemplovment (in Weeks) }\end{array}$ & 1.59 & 0.85 & 1 & 6 & 1017 \\
\hline Duration of Unemployment (in Weeks) ${ }^{a}$ & 12.14 & 12.19 & 0.2 & 52 & 1210 \\
\hline Education & 2.88 & 1.2 & 1 & 5 & 4519 \\
\hline $1<$ High School $\quad(14.12 \%)$ & & & & & \\
\hline 2 High School Grad (33.10\%) & & & & & \\
\hline 3 Some College $\quad(26.33 \%)$ & & & & & \\
\hline 4 College Grad & & & & & \\
\hline $5>$ College & & & & & \\
\hline
\end{tabular}

Notes: The table reports summary statistics for the baseline estimates. The sample is restricted to head of households who are between 25 and 65 years old in 2004, and at least three years must have passed since the individual's last unemployment spell. ${ }^{a}$ statistics conditional on an individual having a past unemployment episode. A worker changes industries if the industry in which s/he work prior to their last unemployment spell is different than their current industry. Individuals without a past unemployment spell are assumed to have changed industries if the industry in which they worked in 1995 is different from their present industry. Long-duration unemployment is an unemployment episode lasting more than 26 weeks; a short-duration unemployment spell is 26 weeks or less. 
Figure A.1: Unemployment Duration (Current vs. 2005)

\section{Distribution of Unemployment by Duration (Total Unemployed 100\%)}

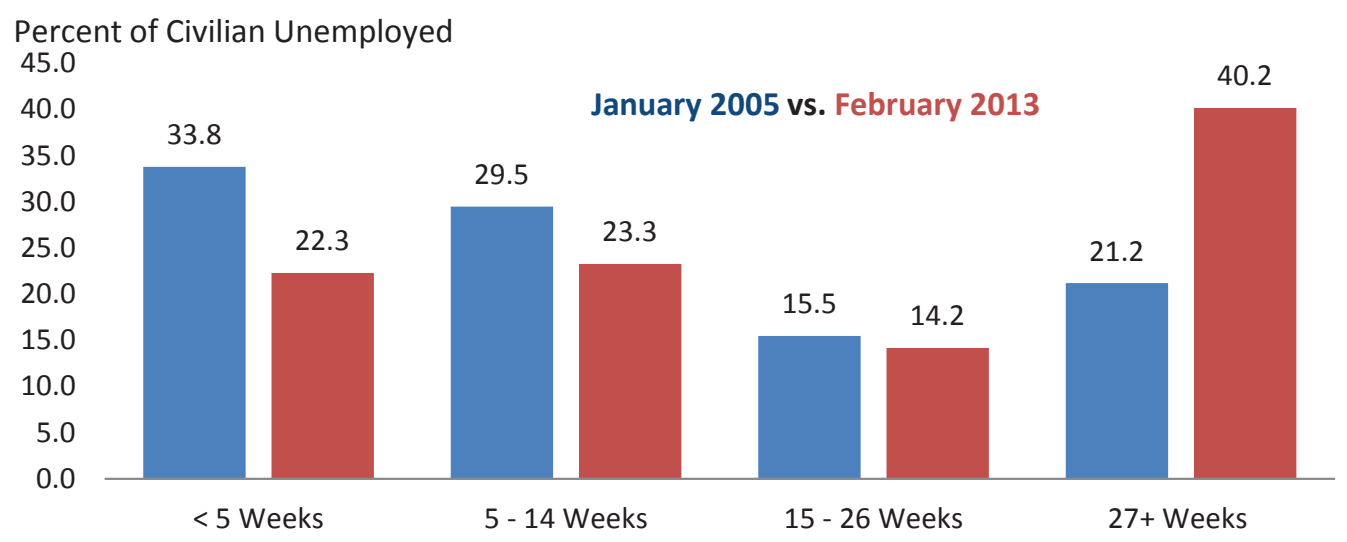

Source: Bureau of Labor Statistics/Haver Analytics. 